\title{
Effects of exogenous melatonin on prolactin secretion, lactogenesis and reproductive seasonality of adult female red deer (Cervus elaphus)
}

\author{
G. W. Asher, F. A. Veldhuizen, C. J. Morrow and \\ D. M. Duganzich
}

New Zealand Pastoral Agriculture Research Institute, Ruakura Agricultural Centre, Private Bag 3123, Hamilton, New Zealand

\begin{abstract}
The effects of administration of exogenous melatonin to pregnant red deer hinds on prolactin secretion, lactogenesis and reproductive seasonality were studied. Mature hinds $(n=23)$ were allocated to one of four treatments. Hinds in treatment I $(n=6)$ each received two subcutaneous melatonin implants (Regulin) at monthly intervals starting on 2 October, about 80 days before expected parturition. Hinds in treatment $2(n=6)$ received similar treatment starting on 2 November, about 40 days before calving, whereas hinds in treatment $3(n=5)$ received treatment starting on the actual day of calving (about 10 December). Final implants were delivered on 1 February, with overall treatment durations of 150,120 and 90 days for treatments $1-3$, respectively. Hinds in treatment $4(n=6)$ served as controls and received no melatonin treatment. Blood samples were taken twice a week from September to May, and plasma was analysed for progesterone and prolactin. Mammary development was assessed by palpation score (0-5) twice a week from October to April inclusive, and liveweights were recorded at least every two weeks throughout the trial. Calving occurred between 28 November and 24 December, with no significant differences among treatments $(P>0.10)$. Hinds in treatment 1 exhibited significant retardation of mammary gland development and liveweight gain leading up to parturition $(P<0.01)$. Furthermore, sex-adjusted calf birth weights were on average $3 \mathrm{~kg}$ lighter for treatment $I(P<0.05)$, with all calves either removed for bottle-rearing or having died within a few hours of birth. Failure of lactogenesis in treatment $I$ was characterized by the presence of underdeveloped, hard mammary tissue devoid of expressible milk. Hinds in treatments 2-4 all exhibited full lactation and successfully reared their calves, and there were no significant differences in calf weaning weight and growth rates. Likewise, there were no significant differences in mean liveweight or lactation score profiles. Mean plasma prolactin concentrations varied significantly between treatments $(P<0.05)$, and control hinds exhibited a marked seasonal pattern of secretion which reached a peak at calving. However, hinds in treatments 1 and 2 failed to show any discernible seasonal increase in mean plasma prolactin concentrations, whereas there was a marked increase in mean prolactin concentrations in hinds in treatment 3 up to parturition, but concentrations decreased rapidly thereafter relative to those of control hinds. Melatonin treatment significantly advanced the date of first oestrus and decreased the postpartum-oestrus interval $(P<0.05)$. It was concluded that initiation of melatonin implant treatment about 80 days before parturition compromises mammary and fetal development in red deer hinds. However, the role of prolactin was not demonstrated conclusively.
\end{abstract}

\section{Introduction}

Red deer (Cervus elaphus scoticus) reproduce seasonally, and the onset of breeding occurs in autumn and calving occurs in summer (Guinness et al., 1971). The calving season and subsequent period of lactation of farmed red deer in New Zealand generally coincide with feed deficits owing to the

Received 30 November 1992 natural senescence of pasture and often effects of drought (Asher and Adam, 1985). Advancement of the calving season by up to 2 months would better align the high energy demands of lactation with peak pasture production and quality in spring, which could facilitate increased lactational yields and calf growth rates.

The breeding season of red deer and other temperate-zone cervids is under photoperiodic control (Marshall, 1937; Jaczewski, 1954), which is mediated by circadian variations in 
the secretion of the pineal hormone, melatonin (Bittman et al., 1983). Several recent studies on red deer have shown that advancement of seasonal reproductive activity can be achieved following delivery of exogenous melatonin in summer, either by oral administration (Adam and Atkinson, 1984; Nowak et al., 1985; Adam et al., 1986, 1989), daily injection (Webster and Barrell, 1985) or subcutaneous implants (Lincoln et al., 1984; Webster et al., 1986, 1991; Fisher et al., 1988; Asher, 1990). However, the degree of advancement elicited is strongly correlated with the seasonal timing of initiation of treatment in the previous summer (Asher, 1990), whereby oestrus advancements of greater than 30 days necessitate the start of melatonin treatment 100-120 days after the winter solstice (that is October in the southern hemisphere). Although this presents few management problems when treating prepubertal red deer hinds ( 16 months old), similar treatment regimens for adult hinds superimpose the initiation of exogenous melatonin delivery with the later stages of pregnancy, which is normally terminated $150-180$ days after the winter solstice.

Few studies have investigated the effects of exogenous melatonin treatment during late pregnancy on the survival of neonates and on lactogenesis. Recent studies on farmed fallow deer (Dama dama), involving the administration of s.c. melatonin implants to adult does during the last 40 days of gestation, indicated a high incidence (4 of 6 does) of failure of lactogenesis at parturition, resulting in the death of fawns born to affected does (Asher et al., 1988). As prolactin has been shown to be essential for normal initiation of lactation in sheep (Fulkerson et al., 1975; Gow et al., 1983), cattle (Karg and Schams, 1974; Akers et al., 1981) and goats (Hart and Morant, 1980), it was postulated that failure of lactogenesis in the fallow deer does may have been due to a reduction in endogenous prolactin secretion in response to the suppressive effects of exogenous melatonin (Asher et al., 1988). Certainly, the delivery of exogenous melatonin has been associated with a dramatic reduction in prolactin secretion in female sheep (Poulton et al., 1986) and red deer (Adam et al., 1989). However, oral administration of melatonin to pregnant red deer hinds, initiated about 40 days before calving, was not associated with either an immediate reduction in prolactin secretion (as seen in nonpregnant hinds) or failure of lactogenesis at calving (Adam et al., 1989). Likewise, experimental reversal of photoperiod did not inhibit lactogenesis in red deer hinds (Adam et al., 1992).

The contrasting results on lactogenesis in the studies on fallow deer (Asher et al., 1988) and red deer (Adam et al., 1989, 1992) may indicate either a significant species difference in response to exogenous melatonin or the differential effects of two differing forms of melatonin delivery (i.e. implantation versus oral). As s.c. melatonin implants are commercially applied to alter red deer reproductive patterns in New Zealand (Barry and Wilson, 1991), it is important to determine any potentially detrimental effects that treatment may have on overall reproductive performance. In the study reported here, the effects of administration of exogenous melatonin, via s.c. implants, to pregnant red deer hinds on prolactin secretion, lactogenesis and reproductive seasonality were investigated. The effect of treatment on calf survival, calf growth and reproductive seasonality of hinds was also evaluated.

\section{Materials and Methods}

\section{Animals and management}

A total of 23 mature (more than 4 years old), pregnant red deer hinds on the Ruakura Agricultural Centre $\left(37^{\circ} 46^{\prime} \mathrm{S}\right.$, $175^{\circ} 20^{\prime} \mathrm{E}$ ) were used in the study. The hinds were selected on the basis of a synchronized predicted calving pattern (10 December \pm 10 days), assessed in June 1990 by rectal ultrasonography of fetal size (White et al., 1989; Wilson and Bingham, 1990). The deer were grazed on ryegrass-white clover pastures as a single group with a mature melatonintreated stag from 7 September 1990 until 30 May 1991. This study was performed following mandatory approval by the Animal Ethics Committee of the Ruakura Agricultural Centre.

\section{Trial protocol}

Each hind was allocated to one of four treatments on the basis of liveweight (liveweight range: $88-115 \mathrm{~kg}$ ). Hinds in treatment $I(n=6)$ each received two s.c. melatonin implants (Regulin: Schering Agrochemicals, NSW) at monthly intervals from 2 October (i.e. about 80 days before predicted parturition) to 1 February (about 150-day treatment). Hinds in treatment 2 $(n=6)$ each received two melatonin implants each month from 2 November (i.e. about 40 days before predicted parturition) to 1 February (about 120-day treatment). Hinds in treatment 3 $(n=5)$ each received two implants each month from parturition (early December) until I February (about 90-day treatment). In all cases implants were placed at the base of the left ear. Hinds in treatment $4(n=6)$ served as controls and received no melatonin treatment. The stag received the same treatment protocol as hinds in treatment 1 . The Regulin implantation schedule was based on previous studies on red deer that demonstrated effective delivery of physiological (night time) concentrations of melatonin $\left(50-200 \mathrm{pg} \mathrm{ml}^{-1}\right.$ plasma) for periods of 30-40 days (Asher, 1990; Webster et al., 1991).

\section{Collection of blood samples}

Blood samples were taken from hinds by jugular venepuncture into $10 \mathrm{ml}$ heparinized evacuated tubes twice a week from 4 September to 1 May. The deer were restrained individually in a pneumatically operated crush while samples were taken. Blood samples were centrifuged for $25 \mathrm{~min}$ at $1000 \mathrm{~g}$ within 30 min of collection, and the plasma was stored at $-10^{\circ} \mathrm{C}$ until required for assay.

\section{Lactation and liveweight recording}

Mammary development was assessed by palpation twice a week from 12 October until 12 April, two weeks after the last calf was weaned. The udders were scored on a scale from 0 to 5 , representing the range of development from no palpable mammary tissue (0) to full mammary and teat extension (5). All scoring was performed by a single observer while the hinds were restrained in the crush. Liveweights were recorded at least every two weeks during the trial 
period, and once a week during the calving period (late November to mid-January).

\section{Calving records}

Hinds were monitored twice a day during the calving period and all calves were tagged within $12 \mathrm{~h}$ of birth. Calf birth date, birth weight, sex and dam were recorded. Calves were removed for bottle-rearing if their dams failed to initiate lactation within $12 \mathrm{~h}$ of birth. Surviving calves were weighed and weaned at exactly 12 weeks of age, necessitating successive removal of calves from 2 to 19 March.

\section{Defection of oestrus}

The stag was fitted with a ram mating harness (Fergus: Merck, Sharp and Dohme NZ Ltd, Auckland) from 1 February to 10 May. Crayons were replaced twice a week and daily observations were performed to record crayon mating marks on hinds (Asher, 1990). The date of first oestrus for each hind was determined either from direct evidence of mating $(n=16)$ or estimated from plasma progesterone profiles as the sampling date that preceded a sustained increase $\left(>1.0 \mathrm{ng} \mathrm{ml}^{-1}\right)$ in plasma progesterone concentrations $(n=7)$.

\section{Hormone radioimmunoassays}

Plasma progesterone concentrations were measured in duplicate by direct radioimmunoassay (Asher, 1990). The antiserum was raised in a rabbit against progesterone-11BSA conjugate and used at a final dilution of 1:200 000 . ${ }^{125}$ I-labelled progesterone (Amersham International plc; Amersham) was used as the tracer. The only significant crossreaction of a wide range of steroids tested in the assay was cholesterol (1.5\%). Serial dilutions of pooled plasma samples with high concentrations of immunoreactive progesterone gave inhibition curves parallel to those generated for progesterone in buffer. All samples from an individual hind were included within a single assay. Low, medium and high progesterone control samples were included at frequent intervals in each assay. The interassay coefficients of variation ( $n=26$ assays) were $19.1 \%$ for the low control (mean concentration $\left.=0.46 \mathrm{ng} \mathrm{ml}^{-1}\right), 13.0 \%$ for the medium control (4.94 $\mathrm{ng} \mathrm{ml}^{-1}$ ) and $11.7 \%$ for the high control (10.1 ng $\left.\mathrm{ml}^{-1}\right)$. The intra-assay coefficients of variation were $15.6,6.2$ and $7.3 \%$, respectively, for the three control samples. Sensitivity, defined as the first point on the standard curve that was significantly different from zero, was $0.10 \mathrm{ng} \mathrm{ml}^{-1}$.

The concentrations of plasma prolactin were measured in duplicate by direct radioimmunoassay using the NIDDK ovine prolactin kit, but replacing ovine prolactin standards (oPRL AFP $4328 \mathrm{C}$ ) with cervine prolactin standards (cePRL AFP 10263 B). All aspects of the assay method were as per instructions provided with the NIDDK kit. The assay standards, constituted in buffer, consisted of highly purified prolactin extracted from red deer pituitary glands recovered from abattoir-slaughtered animals in New Zealand. Extraction, purification and characterization of the cervine prolactin were conducted in the laboratory of A. F. Parlow (Habor-UCLA
Medical Centre, Torrance, CA) using the procedures described by Li et al. (1987). Parallelism between oPRL and cePRL was demonstrated using anti-oPRL antiserum (AFP 962379) and ${ }^{125}$ I-labelled oPRL ligand (oPRL AFP $4328 \mathrm{C}$ ). However, greater displacement of ovine standards was evident at higher ligand mass (>10 ng per tube) leading to higher concentration estimation on the cervine standard curve for plasma samples $>100 \mathrm{ng} \mathrm{ml}^{-1}$. The effective upper limit of the assay was $100-200 \mathrm{ng} \mathrm{ml}^{-1}$, and all samples registering above $100 \mathrm{ng} \mathrm{ml}^{-1}$ on initial assay were re-assayed following 1:3 dilution in cervine plasma with a low concentration $\left(<0.5 \mathrm{ng} \mathrm{ml}^{-1}\right)$ of immunoreactive prolactin. Cervine plasma samples, with mean concentrations of $11.5,83$ and $155 \mathrm{ng} \mathrm{ml}^{-1}$ prolactin, were included as controls at frequent intervals in each assay run $(n=12)$. The interassay coefficients of variation were $9.9,9.7$ and $13.9 \%$, respectively, and the intra-assay coefficients of variation were $12.1,6.9$ and $17.8 \%$, respectively. The sensitivity of the standard curve was $2 \mathrm{ng}$ prolactin $\mathrm{ml}^{-1}$.

\section{Statistical analyses}

Data were subjected to analysis of variance (Genstat V: Lowes Agricultural Trust, Rothamstead Experimental Station) following logarithmic transformation of plasma progesterone and prolactin concentrations and square-root transformation of lactation scores. Means are presented with either the standard error of difference (SED) or least significant difference (LSD), based on pooled variance.

\section{Results}

\section{Parturition and oestrus}

All 23 hinds in the trial calved between 28 November and 24 December 1990; there were no significant differences in mean calving date between treatments $(P>0.1$; Table 1$)$. Sex-adjusted calf birth weights were significantly lighter, by an average of about $3 \mathrm{~kg}$, for hinds in treatment $I(P<0.05$; Table 1). While all calves born to hinds in treatments $2-4$ survived to weaning at 12 weeks of age (Table 1), the six calves born to hinds in treatment $I$ were either found dead within $3-4 \mathrm{~h}$ of birth $(n=2)$ or were removed from their dams within $12 \mathrm{~h}$ of birth $(n=4)$ because of lactational failure. Only one of these calves ultimately survived bottlerearing; the other three died within 2-3 days and were assessed as being nonviable (i.e. unable to walk or adequately suckle). The mean sex-adjusted weaning (12-week) weights and growth rates of surviving calves (treatments 2-4) were not significantly different between treatments $(P>0.1$; Table 1).

The mean date of first oestrus varied significantly between treatments, with all melatonin-treated hinds (treatments I-3) exhibiting first oestrus of the 1991 season significantly earlier than did control hinds (Table 1 ). Differences between treatments 1,2 and 3 were apparent but not significant $(P>0.10)$. However, the mean postpartum-oestrus interval showed significant differences between control hinds and melatonintreated hinds $(P<0.05)$ and between melatonin treatment 
Table 1. Mean parameters and SED for parturition, calf weights, onset of oestrus and postpartum intervals in red deer

\begin{tabular}{|c|c|c|c|c|c|c|c|c|}
\hline Treatment $^{a}$ & $\begin{array}{l}\text { Number of } \\
\text { hinds }\end{array}$ & $\begin{array}{l}\text { Calving day } \\
1990\end{array}$ & $\begin{array}{c}\text { Calf birth } \\
\text { weight }(\mathrm{kg})^{\mathrm{b}}\end{array}$ & $\begin{array}{l}\text { Calf } \\
\text { survival }\end{array}$ & $\begin{array}{l}\text { Calf weaning } \\
\text { weight }(\mathrm{kg})^{\mathrm{b}}\end{array}$ & $\begin{array}{l}\text { Calf growth } \\
\text { rate }\left(\mathrm{g} \mathrm{day}^{-1}\right)^{\mathrm{b}}\end{array}$ & $\begin{array}{l}\text { Day of first } \\
\text { oestrus } 1991\end{array}$ & $\begin{array}{l}\text { Postpartum-oestrus } \\
\text { interval (days) }\end{array}$ \\
\hline 1 & 6 & 345.8 & 6.07 & $0 / 6^{\mathrm{c}}$ & - & - & 53.0 & 72.2 \\
\hline 2 & 6 & 347.7 & 9.04 & $6 / 6$ & 35.6 & 316 & 63.7 & 80.8 \\
\hline 3 & 5 & 337.4 & 8.94 & $5 / 5$ & 39.0 & 358 & 67.8 & 95.4 \\
\hline Control & 6 & 342.0 & 8.65 & $6 / 6$ & 37.3 & 341 & 81.2 & 104.2 \\
\hline \multicolumn{2}{|c|}{ SED } & 4.7 & 0.72 & - & 2.7 & 25 & 9.9 & 10.1 \\
\hline
\end{tabular}

${ }^{\mathrm{a}}$ Treatment began on days $-80,-40$ and 0 from parturition for treatments 1,2 and 3 , respectively.

bData adjusted by co-variance for calf sex.

'One calf was successfully bottle-reared.

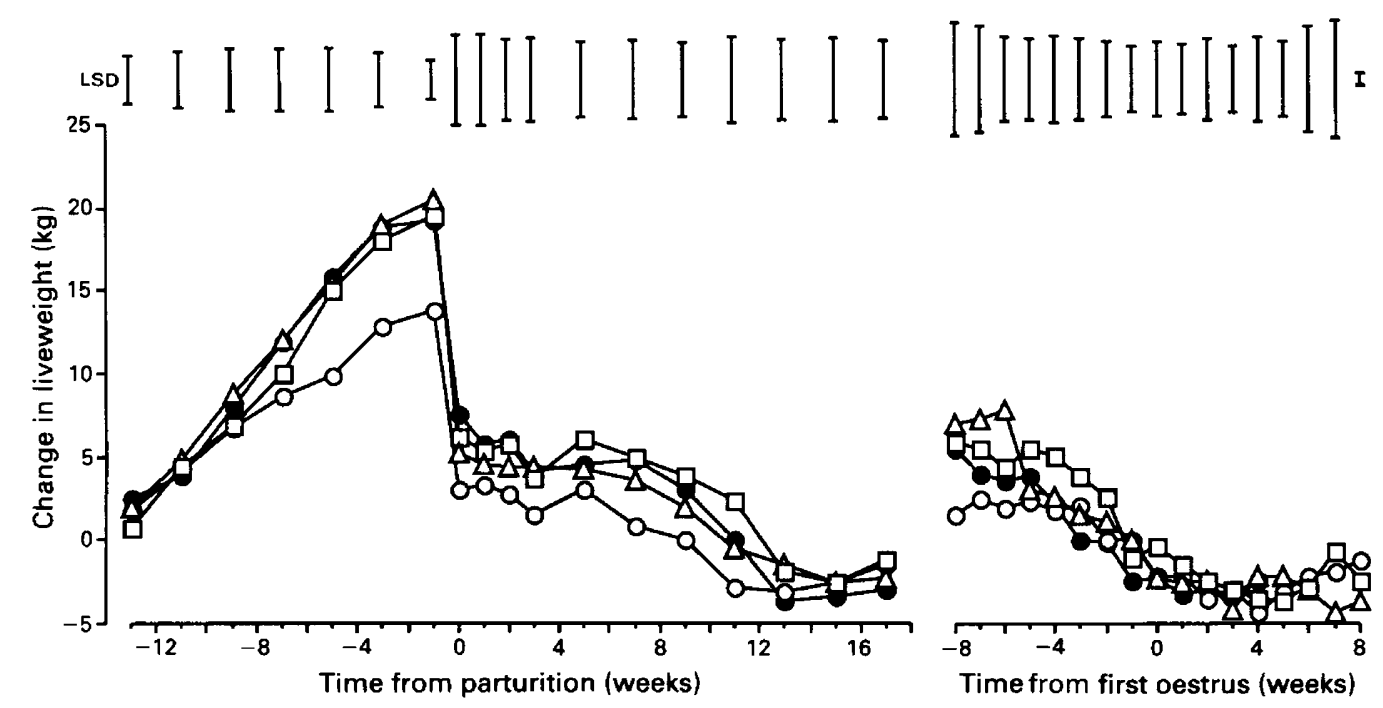

Fig. 1. Profiles of mean liveweight change, normalized about parturition and first oestrus, for red deer hinds in treatments $I(O ;-80$ days), $2(\triangle ;-40$ days), $3(\square ; O$ days) and 4 ( $)$; controls). Vertical bars denote the least significant difference (LSD).

groups $(P<0.05)$, ranging from 104 days for control hinds to 72 days for hinds in treatment $I$ (Table $I$ ).

\section{Hind liveweight changes}

Analysis of hind liveweight changes (difference in liveweight from that recorded on 7 September 1990) indicates significant differences for hinds in treatment $1(P<0.01)$. This was manifest as a reduction in the rate of liveweight increase over the 8 weeks before parturition, such that the differential between hinds in treatment $I$ and all other treatments averaged about $8 \mathrm{~kg}$ just before calving (Fig. 1). All subsequent changes in liveweight did not significantly differ between treatments. In general, a substantial decrease in mean liveweights, of between 15 and $20 \mathrm{~kg}$, was observed at calving. Thereafter, mean liveweights declined by $8-10 \mathrm{~kg}$ over the subsequent 12 weeks when most hinds were lactating, resulting in mean values 3-4 $\mathrm{kg}$ below initial pre-trial (September) weights by the end of the lactational period. For all treatments, first oestrus of the 1991 season occurred during a period of declining mean liveweights, and there were no significant differences between treatments $(P>0.10$; Fig. 1$)$.

\section{Lactation}

Profiles of mean lactation scores over the period from -6 to +17 weeks about parturition (Fig. 2) did not show any significant differences for hinds in treatments 2-4; initial mean scores were $<1.06$ weeks before calving and increased progressively to attain peak mean values of 4.8 at calving. Thereafter, mean lactation scores declined to about 3.0 by the eighth week from calving. Calf removal at 12 weeks was associated with a subsequent increase in mean scores to about 4.0 over 2 weeks, followed by a rapid and progressive decline to attain low mean scores of $<0.5$ by 17 weeks from calving (Fig. 2).

Hinds in treatment 1 exhibited significantly different mammary development $(P<0.01)$ that was ultimately interpreted as failure of lactogenesis. While mean lactation scores increased during the preparturient period, the maximum mean score 

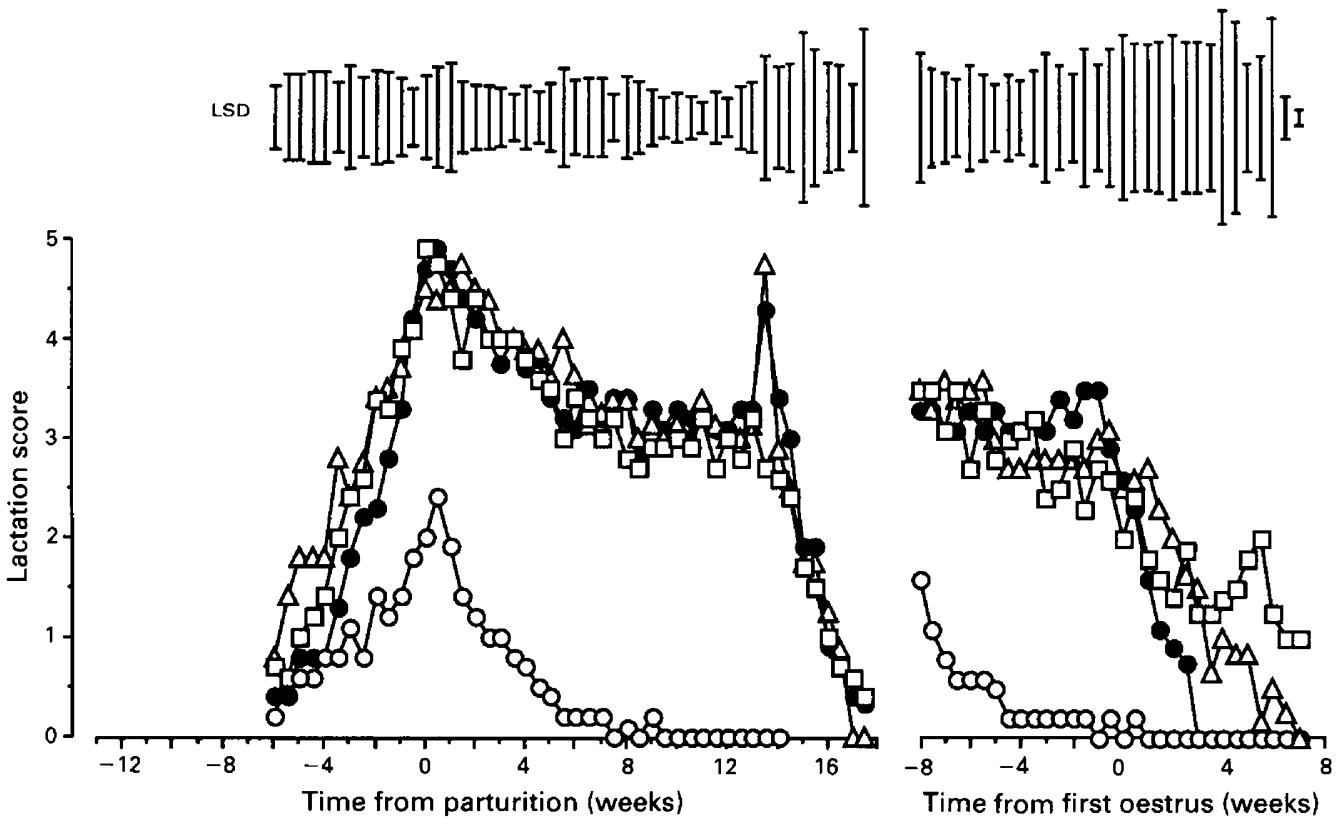

Fig. 2. Profiles of mean lactation scores, normalized about parturition and first oestrus, for red deer hinds in treatment $1(0 ;-80$ days), 2 ( $\triangle ;-40$ days), 3 ( $\square ; 0$ days) and 4 ( 0 ; controls). Vertical bars denote the least significant difference (LSD).

within one week of calving was only 2.4 (Fig. 2). At this point, palpable mammary tissue was described as being 'hard' and no milk could be expressed. The subsequent decline in mean lactation scores, which occurred in the absence of any suckling stimulus (all calves had died or were removed), was rapid, and no mammary tissue was palpable 8 weeks after calving (Fig. 2).

When the data were normalized about first oestrus of the 1991 breeding season (Fig. 2), it was evident that mean lactation scores leading up to oestrus were significantly lower for hinds in treatment $\mathrm{I}(P<0.05)$. However, mean scores declined for all hinds in treatments 2-4 within 4-6 weeks after oestrus, at which point there were no differences between treatments $(P<0.10)$.

\section{Plasma prolactin profiles}

The control hinds exhibited a profile of concentrations of plasma prolactin characterized by an increase in mean concentrations from about $10 \mathrm{ng} \mathrm{ml}^{-1} 12$ weeks before calving to about $200 \mathrm{ng} \mathrm{ml}^{-1}$ at calving (Fig. 3). Mean concentrations fluctuated about a plateau of about $120 \mathrm{ng} \mathrm{ml}^{-1}$ for 8 weeks after calving, and then declined progressively to $<20 \mathrm{ng} \mathrm{ml}^{-1}$ 16 weeks post partum.

The mean plasma prolactin profiles of hinds in treatments 1 and 2 were significantly different from that of the control hinds $(P<0.01)$. In both cases, mean values were significantly lower from 4 weeks before calving to 12.5 weeks post partum. The profiles of these two groups were essentially similar, and significantly different means occurred on only four occasions up to 4 weeks from calving; at all other times there were no significant differences $(P>0.05)$. Mean profiles for treatments 1 and 2 were characterized by relatively low concentrations (<50 ng ml${ }^{-1}$ ) throughout the study, although occasional fluctuations up to $90 \mathrm{ng} \mathrm{ml}^{-1}$ were observed for treatment 1 between 12 and 8 weeks before calving.

Hinds in treatment 3 exhibited a mean profile that was initially similar to that observed for control hinds. However, mean plasma prolactin concentrations declined 2-3 weeks after parturition/melatonin implantation, and remained below $30 \mathrm{ng}$ $\mathrm{ml}^{-1}$ from 8 weeks post partum.

Mean plasma prolactin concentrations were not discernibly different for hinds in treatment $I-3$ by 8 weeks post partum $(P<0.01)$, although those of control hinds were significantly increased at this stage $(P<0.01)$. By 16 weeks post partum, mean values for all treatments were similar $(P>0.1)$. Likewise, mean concentrations at first oestrus (Fig. 3) were not significantly different for any treatment $(P>0.1)$ and were uniformly low $\left(<20 \mathrm{ng} \mathrm{ml}^{-1}\right.$ ).

\section{Plasma progesterone profiles}

Mean concentrations of plasma progesterone (Fig. 4) during the preparturient period were increased between 2 and $6 \mathrm{ng}$ $\mathrm{ml}^{-1}$ for all treatments. Parturition was associated with a precipitous decline in concentrations of plasma progesterone in all hinds, and mean values immediately after calving were $<0.3 \mathrm{ng} \mathrm{ml}^{-1}$ for all treatments. The anoestrous period was characterized by low mean concentrations of plasma progesterone $\left(<0.6 \mathrm{ng} \mathrm{ml}^{-1}\right)$ for all treatments. However, the duration of the anoestrous period (i.e. postpartum-oestrus interval; Table 1) differed significantly between treatments $(P<0.05)$, and was shortest for treatment 1 and longest for treatment 4 (controls). This trend was manifest as differential timing of increased progesterone secretion as a consequence of reinstatement of ovulatory (luteal) activity. Postpartum mean plasma progesterone concentrations exceeded $1.0 \mathrm{ng} \mathrm{ml}^{-1}$ at weeks 


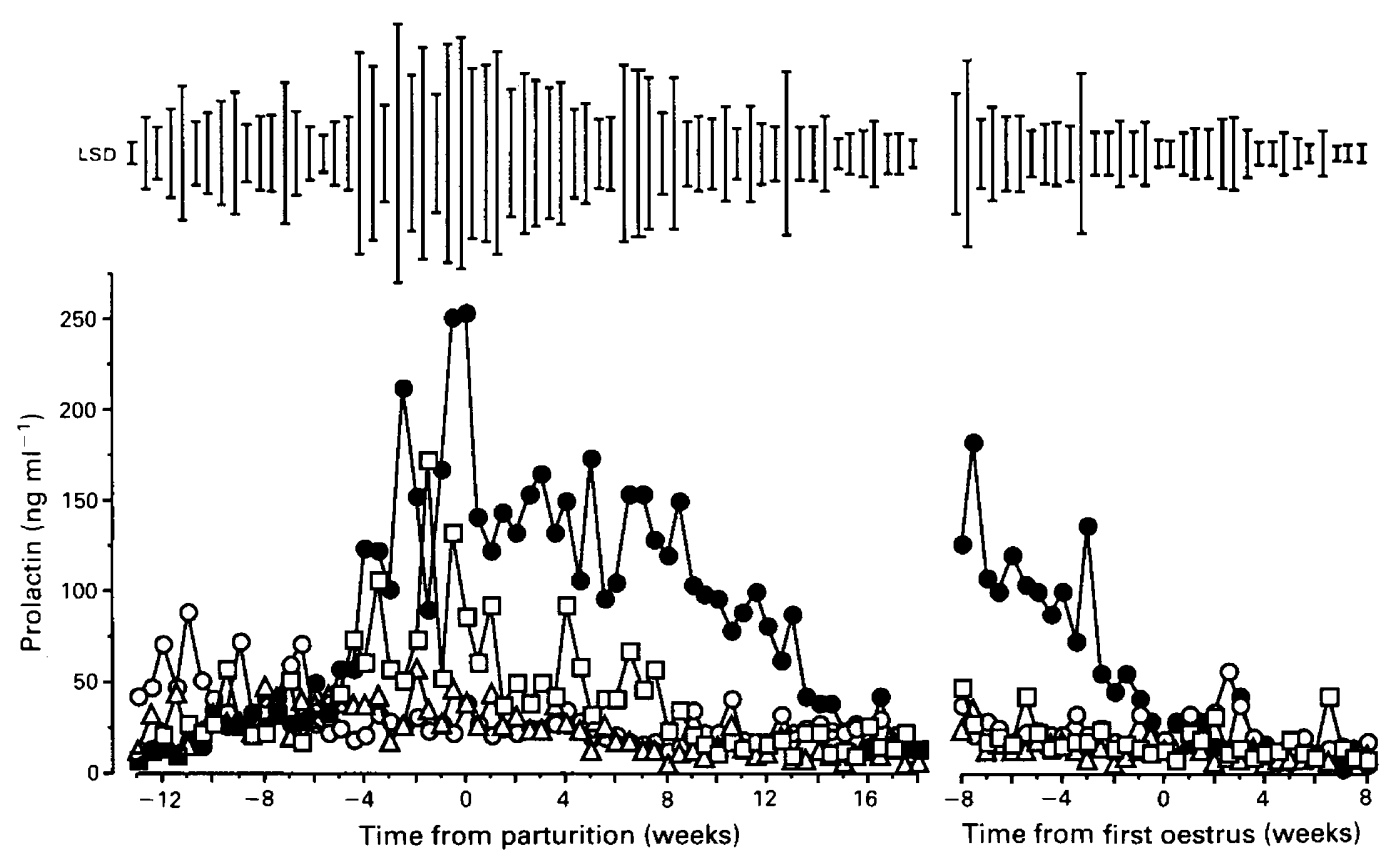

Fig. 3. Profiles of mean concentrations of prolactin in plasma normalized about parturition and first oestrus, for red deer hinds in treatments 1 ( $O ;-80$ days), $2(\triangle ;-40$ days), 3 ( $\square ; 0$ days) and 4 (O; controls). Vertical bars denote the least significant difference (LSD).
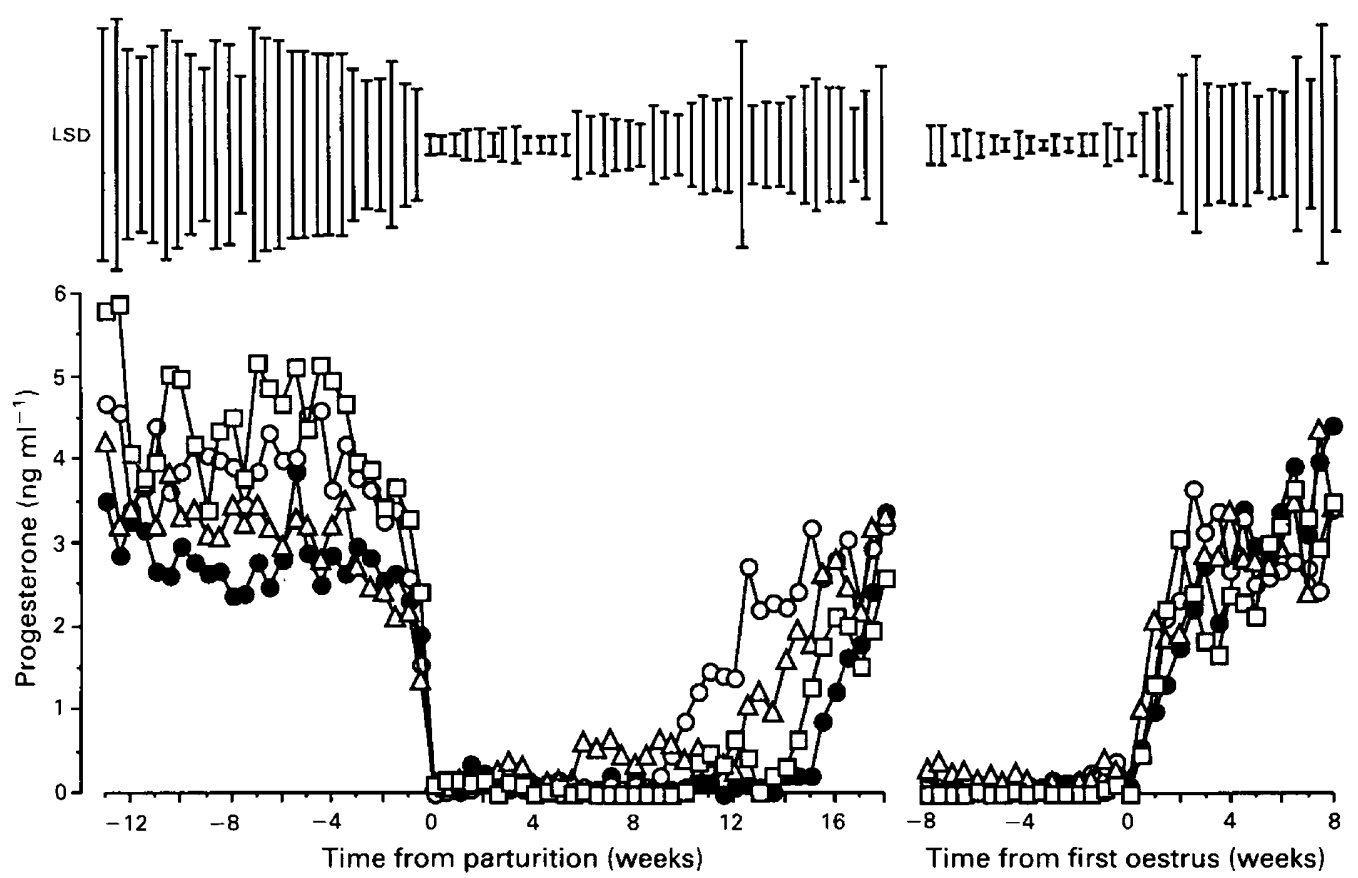

Fig. 4. Profiles of mean concentrations of progesterone in plasma normalized about parturition and first oestrus, for red deer hinds in treatments $1(O ;-80$ days), $2(\Delta ;-40$ days), 3 ( $\square ; 0$ days) and $4(O$; controls). Vertical bars denote the least significant difference (LSD).

$10,12,15$ and 16 for treatments $1-4$, respectively. Plasma progesterone data normalized about first oestrus (Fig. 4) demonstrated overall similarity between treatments in progesterone secretion associated with the onset of ovulatory activity.

\section{Discussion}

The attainment of a significant degree of seasonal reproductive advancement (i.e. more than 30 days) in mature red deer hinds requires the initiation of exogenous melatonin treatment during 
the latter phase of gestation in spring and early summer. This is due to the relatively long gestation (234 days; Guinness et al., 1971) and short postpartum-oestrus interval (120 days), whereby latency of 'cause and effect' between initiation of simulated 'short days' and the ovarian response (90-150 days; Asher, 1990) necessitates the imposition of treatment on pregnancy. The present study has demonstrated that certain aspects of reproductive performance can be compromised by the initiation of melatonin implant treatment at about 80 days before parturition, and raises questions about the effect of melatonin treatment on fetal and mammary development.

The conclusion drawn from the present study is that there appears to be a critical phase during late gestation when continuous infusion of exogenous melatonin interferes with normal development of both the fetus and the developing mammary tissue. Initiation of melatonin implant treatment about 80 days before parturition was associated with significantly reduced hind liveweight gains and calf birth weights (and calf survival), as well as apparent failure of lactogenesis, whereas treatment starting at about 40 days before parturition or on the actual day of calving did not elicit any apparent effects on hind weights, birth weights or lactation relative to control hinds. It should be noted at this point that even though the melatonin implantation regimen was designed to increase concentrations of plasma melatonin continuously to those approaching normal night-time values in this species (Asher, 1990; Webster et al., 1991), continuous infusion of exogenous melatonin does not mimic short photoperiods, and the treatment must therefore be considered pharmacological rather than physiological. In this respect, pregnant red deer hinds subjected to short photoperiods from about 19 weeks of gestation (i.e. 14 weeks from parturition) showed a normal lactational response (Adam ef al., 1992), in marked contrast to the results of the present study.

In the study reported here, hinds in treatment 1 showed a marked reduction in prepartum liveweight gain relative to all other hinds, resulting in an overall mean liveweight difference of about $8 \mathrm{~kg}$ just before calving. Exogenous melatonin treatments reduce liveweight gains in young red deer (Fisher et al., 1988, 1990; Asher, 1990), and the present data indicate that in late pregnancy the effect may be due to a reduction in fetal growth, as evidenced by reduced calf birth weights. This finding indicates that conceptus development is sensitive to pharmacological concentrations of melatonin, although the precise mechanisms involved cannot be determined from the present data. Irrespective of the mode of action, the overall effect on calf viability and survival was dramatic, with all but one of the calves born to hinds in treatment 1 failing to survive beyond a few days of age. This alone strongly mitigates against such early treatment regimens in pregnant hinds.

Perhaps the most conclusively demonstrated effect of initiating implant treatment about 80 days before parturition is the failure of lactogenesis in all hinds in treatment 1 . This contrasts with full lactational development in all hinds in treatments 2-4. Profiles of mean lactation scores indicate that mammary development occurred from about 6 weeks before parturition, culminating in peak development within a few days of calving. Thus, imposition of melatonin implant treatment on pregnancy in treatment 1 probably occurred before the natural initiation of mammary tissue growth, whereas all other treatment regimens were initiated at various intervals after tissue growth had commenced. This finding again suggests that there is a critical phase, between -80 and -40 days from parturition, during which development of mammary tissue is normally initiated. The fact that prior treatment with exogenous melatonin can strongly affect development, whereas later treatment initiation appears to have no effect at all, raises questions about the endogenous cues responsible for the growth of mammary cells. In particular, early initiation of implant treatment may block normal cellular development in the mammary gland either by the direct inhibition of cellular processes, indirectly by perturbation of maternal endocrine events (for example, prolactin or steroid secretion), or by retardation of fetal and placental growth (and hence suppression of such factors as placental lactogen). Failure of lactogenesis in treatment $I$ was not associated with complete inhibition of mammary development: at the time of calving, expanded mammary tissue was palpable as a hard mass within the udder and no milk could be expressed. In the other treatments, mammary tissue was spongy and milk was easily expressed.

The removal/death of all calves born to hinds in treatment 1 removed any potential suckling stimulus from these hinds, and the subsequent rapid regression of mammary tissue was predictable. However, given the degree of underdevelopment at calving, it would seem highly unlikely that an appropriate lactation would have been instigated if a suckling stimulus had occurred. The failure of later treatments (i.e. treatments 2 and 3) to affect mammary development and subsequent lactation is consistent with previous studies on red deer, in which exogenous melatonin was delivered orally starting 37 days before parturition (Adam et al., 1989) or by implant after parturition (Fisher and Fennessy, 1990). Thus, the maintenance of established lactation in this species is not noticeably affected by exogenous melatonin. This also appears to be the case for fallow deer (Asher et al., 1988). The increase in mean lactation score immediately after calf removal at 12 weeks of age probably represents increased udder volume from unharvested milk. However, subsequent regression of entire mammary tissue was complete 5 weeks after weaning and no complications were observed.

The pituitary hormone prolactin is secreted in a manner that reflects the photoperiodic cycle, with high and low concentrations of plasma prolactin being concomitant with long and short daylengths, respectively, as demonstrated in ewes (Thimonier et al., 1978). As expected for a seasonal species such as red deer, the control hinds in the present study exhibited a marked increase in plasma prolactin concentrations concomitant with increasing daylength, followed by a decline with decreasing daylength. These data are consistent with those of Adam $e$ al. $(1989,1992)$. It is interesting to note that in all of these studies marked increases in apparent prolactin secretion were not observed until about $6-8$ weeks before parturition, at about the same time that initial mammary development was observed in the present study.

The consequence of a reduction in prolactin secretion, mediated by exogenous melatonin delivery, on lactation observed in this study is noteworthy. Prolactin stimulates mammary parenchymal gland growth, either directly or synergistically with steroid hormones, in several species of laboratory animals (Topper and Freeman, 1980; Muldoon, 1987). In 
this respect, an adequate concentration of prolactin secretion has been shown to be essential for normal initiation of lactation in sheep (Fulkerson et al., 1975; Gow et al., 1983), cattle (Karg and Schams, 1974; Akers et al, 1981) and goats (Hart and Morant, 1980). Suppression of prolactin secretion by exogenous melatonin has been demonstrated for sheep (Kennaway et al., 1982; Symons et al., 1983; Poulton et al., 1986) and red deer (Nowak et al., 1985; Webster and Barrell, 1985; Adam et al., 1987, 1989; Milne et al., 1990). It would therefore be reasonable to assume that exogenous melatonin treatment may inhibit lactogenesis in red deer by suppressing prolactin secretion. Although the present study demonstrated that melatonin implants resulted in a decrease in plasma prolactin concentrations, it was not possible to distinguish statistically between mean concentrations for hinds in treatments 1 and 2 . Both groups exhibited relatively low mean plasma values throughout the study period, but contrasted markedly in lactational development. Furthermore, Adam et al. (1992) demonstrated a marked reduction in mean plasma prolactin concentrations in red deer hinds subjected to short photoperiods from about 14 weeks before parturition, but observed no apparent detrimental effects on lactogenesis. This focuses some doubt on a possible mediatory effect of melatonininduced (or photoperiod-induced) reductions in prolactin secretion on failure of lactogenesis in red deer hinds. Given the markedly circadian pattern of prolactin secretion in red deer hinds (Adam et al., 1989), it is possible that the sampling regimen used in the present study was inadequate to assess the true secretory pattern of prolactin, particularly with respect to detecting differences between treatments 1 and 2 .

There were other aspects of plasma prolactin profiles in the present study that contrasted with previous studies. Adam et al. (1989) showed that reductions in plasma prolactin concentrations following initiation of oral melatonin treatment 37 days before parturition were delayed by about 50 days (i.e. 14 days after calving), which contrasted with more rapid reductions within 21 days in nonpregnant hinds, indicating that pregnancy could in some way override the suppressive effects of exogenous melatonin. In the study reported here, there was a more rapid reduction in prolactin secretion in pregnant hinds, and minimum mean concentrations of prolactin in plasma were observed within 14 days of implantation of melatonin, particularly for hinds in treatment 1 . Furthermore, previous studies involving the treatment of pregnant hinds with either orally administered melatonin (Adam et al., 1989) or short photoperiods (Adam et al., 1992) demonstrated the characteristic parturient increase in prolactin secretion in both treated and control hinds. This feature was notably absent from the mean plasma prolactin profiles of hinds in treatments 1 and 2 in the study reported here. Such contrasting results indicate fundamental differences in the effects of various forms of melatonin delivery on prolactin secretion, perhaps further stressing the implications of pharmacological delivery via s.c. implants. It would appear that the melatonin implantation regimen used in the present study elicited more rigorous control over prolactin secretion than that observed following oral delivery or photoperiod manipulations.

Although evidence presented here that suppression of prolactin secretion causes failure of lactogenesis is equivocal, there is no doubt that reduced plasma concentrations of prolactin had no effect on the maintenance of established lactation. This finding is consistent with other studies on red deer (Adam et al., 1989; Fisher and Fennessy, 1990) and other ruminants (Karg et al., 1972; Hart, 1973), and was evidenced in the study reported here by profiles of mean lactation scores and growth rates of suckled calves for treatments 2 and 3 .

In the present study, melatonin treatment resulted in a significant advancement of first oestrus of the 1991 breeding season and an overall reduction in the postpartum-oestrus interval. The maximum advancement obtained, measured relative to control hinds, was 32 days for hinds in treatment 1 . Although this is less than the 54 days recorded for pubertal hinds under a similar treatment regimen (Asher, 1990), hinds in the two trials were managed differently. In the former study, pubertal hinds were physically separated into treatment groups to avoid possible social facilitation effects on the seasonality of first oestrus, as demonstrated by Fisher et al. (1988). In the present trial, there was the potentially confounding effect of social facilitation from maintaining all hinds in a single group in the presence of a treated stag, irrespective of treatment. Thus, control hinds exhibited oestrus around late March, about 2 weeks earlier than expected within the overall population. There is also the further consideration that hinds in treatment 1 were not lactating, having lost their calves. This may have been a contributing factor to their early return to oestrous activity.

In summary, although treatment of mature red deer hinds with s.c. melatonin implants during the later stages of pregnancy is efficacious in advancing the onset of seasonal ovarian activity, treatment initiated about 80 days before parturition was shown to be associated with retardation of fetal development and failure of lactogenesis, with consequences on hind reproductive productivity.

The authors thank P. G. Kirton, M. Langridge, D. Brears, H. N. Jabbour and other staff of the Ruakura Agricultural Centre for assistance in animal management and data collection. Regulin implants were kindly donated by Schering Agrochemicals Ltd and reagents for the prolactin radioimmunoassay were generously supplied by the National Institute of Diabetes, Digestive and Kidney Diseases (NIDDK), MD, USA, with cervine prolactin supplied by $\mathrm{S}$. Haines, Invermay Agricultural Centre, Mosgiel, NZ.

\section{References}

Adam CL and Atkinson T (1984) Effect of feeding melatonin to red deer (Cervus elaphus) on the onset of the breeding season Journal of Reproduction and Fertility 72 463-466

Adam CL, Moir CE and Atkinson T (1986) Induction of early breeding in red deer (Cervus elaphus) by melatonin Journal of Reproduction and Fertility $\mathbf{7 6}$ $569-573$

Adam CL, Atkinson T and Moir CE (1987) Melatonin lowers plasma prolactin levels in female red deer (Cerous elaphus) Journal of Pineal Research 4 13-20

Adam CL, Moir CE and Shiach P (1989) Plasma prolactin concentrations in barren, pregnant and lactating red deer (Cervus elaphus) given melatonin to advance the next breeding season Animal Reproduction Science 18 77-86

Adam CL, Kyle CE and Young P (1992) Influence of prenatal photoperiod on postnatal prolactin secretion in red deer (Cerous elaphus) Journal of Reproduction and Fertility 95 959-964

Akers RM, Bauman DE, Capuco AV, Goodman GT and Tucker HA (1981) Prolactin regulation of milk secretion and biochemical differentiation of mammary epithelial cells in periparturient cows Endocrinology $10923-30$ 
Asher GW (1990) Effect of subcutaneous melatonin implants on the seasonal attainment of puberty in female red deer (Cervus elaphus) Animal Reproduction Science 22 145-159

Asher GW and Adam JL (1985) Reproduction of farmed red and fallow deer in northern New Zealand. In Biology of Deer Production pp 217-224 Eds PF Fennessy and KR Drew. The Royal Society of New Zealand, Wellington

Asher GW, Barrell GK, Adam JL and Staples LD (1988) Effects of subcutaneous melatonin implants on reproductive seasonality of farmed fallow deer (Dama dama) Joumal of Reproduction and Fertility 84 679-691

Barry TN and Wilson PR (1991) The role and usage of melatonin for deer production Advances in Pineal Research 6 249-258

Bittman EL, Dempsey RJ and Karsch FJ (1983) Pineal melatonin secretion drives the reproductive response to daylength in the ewe Endocrinology 113 2276-2283

Fisher MW and Fennessy PF (1990) A note on melatonin-treated red deer stags advancing the onset of the calving season in hinds Animal Production 51 213-216

Fisher MW, Fennessy PF and Milne JD (1988) Effects of melatonin on seasonal physiology of red deer Proceedings of the New Zealand Society of Animal Production 48 113-116

Fisher MW, Fennessy PF and Johnstone PD (1990) The timing of melatonin treatment affects the seasonal onset of ovarian activity, coat growth and liveweight in young red deer hinds Animal Reproduction Science 23 49-59

Fulkerson WJ, McDowell GH and Fell LR (1975) Artificial induction of lactation in ewes: the role of prolactin Australian Journal of Biological Science $\mathbf{2 8}$ $525-530$

Gow CB, McDowell GH and Jenkin G (1983) The importance of prolactin for initiation of lactation in the pregnant ewe Australian Journal of Biological Science $36 \quad 357-367$

Guinness FE, Lincoln GA and Short RV (1971) The reproductive cycle of the female red deer, Cervus elaphus Journal of Reproduction and Fertility 27 $427-438$

Hart IC (1973) Effect of 2-bromo-a ergocryptine on milk yield and the level of prolactin and growth hormone in the blood of the goat at milking Journal of Endocrinology 57 179-180

Hart IC and Morant SV (1980) Roles of prolactin, growth hormone, insulin and thyroxine in steroid-induced lactation in goats Joumal of Endocrinology 84 343-351

Jaczewski $Z$ (1954) The effect of changes in length of daylight on the growth of antlers in deer (Cervus elaphus L.) Folia Biologica Praha 2 133-143

Karg H and Schams D (1974) Prolactin release in cattle Journal of Reproduction and Fertility $39463-472$

Karg H, Schams D and Reinhardt V (1972) Effects of 2-Br- $\boldsymbol{\alpha}$ ergocryptine on plasma prolactin level and milk yields in cows Experientia 28 574-576

Kennaway DJ, Gilmore TA and Seamark RF (1982) Effect of melatonin feeding on serum prolactin and gonadotropin levels and the onset of seasonal estrous cyclicity in sheep Endocrinology 110 1766-1772

Li CH, Chung D, Bewley TA and Cabrera CM (1987) Elephant prolactin: isolation and characterization International Joumal of Peptide and Protein Research $29472-477$
Lincoln GA, Fraser HM and Fletcher TJ (1984) Induction of early rutting in male red deer (Cervus elaphus) by melatonin and its dependence on LHRH Journal of Reproduction and Fertility 72 339-343

Marshall FHA (1937) On the change over in the oestrous cycle in animals after transference across the equator, with further observations on the incidence of the breeding seasons and the factors controlling periodicity Proceedings of the Royal Society London Series B 122 413-428

Milne JA, Loudon ASI, Sibbald AM, Curlewis JD and McNeilly AS (1990) Effects of melatonin and a dopamine agonist and antagonist on seasonal changes in voluntary intake, reproductive activity and plasma concentrations of prolactin and tri-iodothyronine in red deer hinds Journal of Endocrinology $\mathbf{1 2 5}$ 241-249

Muldoon TG (1987) Prolactin mediation of estrogen-induced changes in mammary tissue estrogen and progesterone receptors Endocrinology 121 14I-149

Nowak R, Elmhirst RN and Rodway RG (1985) A note on the effect of melatonin feeding on the initiation of ovarian activity and on plasma prolactin levels in lactating and non-lactating red deer hinds Animal Production 40 515-518

Poulton AL, English J, Symons AM and Arendt J (1986) Effects of various melatonin treatments on plasma prolactin concentrations in the ewe Journal of Endocrinology 108 287-292

Symons AM, Arendt J and Laud CA (1983) Melatonin feeding decreases prolactin levels in the ewe Journal of Endocrinology 99 41-46

Thimonier J, Ravault JP and Ortavant R (1978) Plasma prolactin variations and cyclic ovarian activity in ewes submitted to different light regimens Annales de Biologie Animale Biochimie et Biophysique 17 459-473

Topper YJ and Freeman CS (1980) Multiple hormone interactions in the developmental biology of the mammary gland Physiology Reviews 60 1049-1106

Webster JR and Barrell GK (1985) Advancement of reproductive activity, seasonal reduction in prolactin secretion and seasonal pelage changes in pubertal red deer hinds (Cervus elaphus) subjected to artificially shortened daily photoperiod or daily melatonin treatments Journal of Reproduction and Fertility 73 255-260

Webster JR, Mackintosh CG, Suttie JM, Fennessy PF, Davis GH and Staples LD (1986) Advancing the breeding season of yearling red deer hinds with melatonin Proceedings of the Endocrine Society of Australia 29 (Supplement 2) Abstract E5

Webster JR, Suttie JM and Corson ID (1991) Effects of melatonin implants on reproductive seasonality of male red deer (Cervus elaphus) Joumal of Reproduction and Fertility 92 1-11

White IR, McKelvey AC, Busby S, Snedon WJ and Hamilton WJ (1989) Diagnosis of pregnancy and prediction of foetal age in red deer by real-time ultrasonic scanning Veterinary Record 124 395-397

Wilson PR and Bingham CM (1990) Accuracy of pregnancy diagnosis and prediction of calving date in red deer using real-time ultrasound scanning Veterinary Record 126 133-135 